\title{
Transformation of Paramedics Healthcare Practices into Policy and Public Health Advocacy in the era of Sustainable Development Goals in the Perspective of Nepal
}

\author{
Surya B. Parajuli, ${ }^{1}$ Heera KC, ${ }^{2}$ Anjali Mishra, ${ }^{1}$ Menuka Shrestha ${ }^{3}$ \\ ${ }^{1}$ Department of Community Medicine, Kathmandu University-Birat Medical College \& Teaching Hospital, \\ Tankisinuwari, Nepal, ${ }^{2}$ Department of Nursing, Purbanchal University-Birat Health College, Biratnagar, Nepal, \\ ${ }^{3}$ Department of Community Health Nursing, Purbanchal University College of Medical and Allied Health Sciences, \\ Gothgaun, Nepal.
}

\section{INTRODUCTION}

Mid-level health care providers are known as paramedics in Nepal. ${ }^{1}$ Paramedic means, "A person trained to give emergency medical care to people who are seriously ill with the aim of stabilizing them before they are taken to hospital." ${ }^{, 2}$ Until now, paramedics are backbone of Nepalese health care system. They are trained for primary level clinical care, health education and promotion activities, health advocacy and literacy, data recording and reporting. ${ }^{3,4}$

Paramedics have been working as a first line manager in remote areas where people are secluded by sophisticated facilities and specialized doctors. Public continuously are benefitted by their clinical care expertise in non-biased manner. They have their contribution in health promotion and specific protection activities such as immunization, nutrition and public health program. ${ }^{5}$ With emphasize on their significant contribution, Nepal government has trained them for recording and reporting through Health Management Information System through which monitoring, planning, organizing, budgetingand evaluation is done accordingly. ${ }^{6}$ In the era of sustainable development goals (SDG), these mid-level health care providers can work effectively to implement principles of primary health care (PHC) to achieve universal health coverage (UHC). ${ }^{7}$ Ministry of Health \& Population released its first draft of national health policy 2017 for public suggestions. ${ }^{3}$ As per draft, Nepal is committed to minimise donor driven health care to sustainable community based national healthcare.

Our health system have already free basic health care at first level as per constitution of Nepal and has its aim to expand referral $\left(2^{\text {nd }} \& 3^{\text {rd }}\right)$ level healthcare through health insurance coverage. To meet these objectives, mid-level health care provider should work as a researcher to generate local evidence based health care practice, local health policy formulation and for better health advocacy at local level as per new constitution of Nepal. In conclusion, we need to transform these work forces for better health policy and advocacy at municipality or rural municipality level.

\section{REFERENCES}

1. Nadia Miniclier Cobb. Transformative Education for Health Professionals. (Cited 2018 Dec 30). Available from:https:// whoeducationguidelines.org/content/nepals health-assistants.

2. Paramedic. (Cited 2018 Dec 30). Available from: https://en.oxforddictionaries.com/ definition/paramedic.

3. Ministry of Health and Population. (Cited 2018 Dec 30). Available from http://mohp.gov.np/en/.

4. Pandey NR. Emergency medicine in Nepal: present practice and direction for future. Int $\mathrm{J}$ Emerg Med. 2016;9(1):20. doi: 10.1186/s12245-

\section{6-0118-3}

5. Peter O'Meara, Michel Ruest, Christine Stirling.Community paramedicine: Higher education as an enabling factor. Australasian Journal of Paramedicine: 2014:11(2). Available from: https://ajp.paramedics.org/index.php/ajp/ article/viewFile/22/29.

6. Epidemiology and Disease Control Division, Nepal. (Cited 2018 Dec 30). Available from: http://www.edcd.gov.np/.

7. Sustainable Development Goals 2016-2030 National (Preliminary) Report 2015. Government of Nepal National Planning Commission. (Cited 2018 Dec 30). Available

Correspondence: Dr. Surya B. Parajuli, Department of Community Medicine, Birat Medical College and Teaching Hospital, Tankisinuwari, Morang, Nepal. Email: drsathii@yahoo.com. Phone: +977-9841794785. DOI: $10.3126 /$ jcmsn.v14i4.22246. Article received: 2018-12-08. Article accepted: 2018-12-22. 
from: http://www.np.undp.org/content/dam/ nepal/docs/reports/SDG\%20final\%20reportnepal.pdf.

Citation: Parajuli SB, KC Heera, Mishra A, Shrestha M. Transformation of Paramedics Healthcare Practices into Policy and Public Health Advocacy in the era of Sustainable Development Goals in the Perspective of Nepal. JCMS Nepal. 2018;14(4): 234-5. 